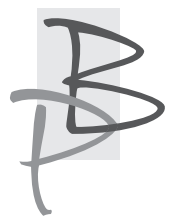

\author{
Jacek Partyka* \\ University of Białystok, Poland \\ https://orcid.org/0000-0003-0734-6138
}

\title{
The Irresistible Charm of Radicalism
}

[rev. Nancy Sinkoff, From Left to Right: Lucy S. Dawidowicz, the New York Intellectuals, and the Politics of Jewish History, Wayne State University Press, 2020, 538 pp. ]

At last, we are given the first, thoroughly researched "intellectual" biography of Lucy S. Dawidowicz (1915-1990), the famous historian of Holocaust studies, the author of the best-selling The War Against the Jews. 1933-1945 (1975), but also a controversial social critic (passionately disputing with Arno J. Mayer, Norman Davis and Ernst Nolte), and a commentator who notoriously strayed from the commonly accepted sentiments of US political correctness (e.g. concerning the postwar wave of feminist movements or the New Left historicism). These days she is mainly associated with the so-called "New York intellectuals," an umbrella term connoting a loose cultural-political group originating from the immigrant Jewish milieu, bent on escaping from the confinement of the cultural ghetto, or, often, leaving behind the constraints of Jewishness entirely (Mary McCarthy, Lionel Trilling, Hannah Arendt,

\footnotetext{
* Jacek Partyka is an Assistant Professor in the Faculty of Philology, University of Bialystok, Poland, where he teaches courses in the history of American literature, intertextuality and comparative studies. His research interests center on American late modernist and postmodernist poetry (Louis Bogan, Elizabeth Bishop, Susan Howe), literary representations of genocide (Edward Lewis Wallant, Cynthia Ozick), W.H. Auden's reinvention of himself as a new poet in the US, and the literature of the Jewish diaspora in New York City.
} 
Daniel Bell, Nathan Glazer, among others). As Irving Howe once noted, from the 1930s onwards the members of that intelligentsia did not tend to look upon their European heritage (both in terms of ideas and sentiments) as significant in their intellectual formation. More specifically, however, and this is the point that is of paramount importance in Nancy Sinkoff's biography of Dawidowicz, the group members were ideologically and intellectually meandering in their sustained (sometimes radical) endeavors before WWII to develop and theorize a Marxist variant of the official communist agenda in the West. Dawidowicz can be seen as a very typical New York intellectual, evolving over the span of her lifetime from an ardent young communist to a democrat staunchly embracing Roosevelt's politics to - and this is her most provocative volte face a fervent advocate of neoconservatism.

Nancy Sinkoff, Professor of Jewish Studies and History at Rutgers School of Arts and Sciences, New Brunswick, NJ, navigates through the facts of Dawidowicz's long and eventful life with the effortless elegance of an experienced and disciplined scholar, pointing to the most probable rationale behind the ideological twists of her protagonist, but tactfully refraining from all-too-easy opinionated valuations, overgeneralizations or moral judgments. Sinkoff seems to be particularly suitable for the writing task she has undertaken, having already edited autobiographical fragments of Dawidowicz, From that Place and Time: A Memoir, 1938-1947 (2008). It is worth noting, especially for readers in Poland, that her research field, apart from Jewish history, is mainly oriented towards the early modern Polish and European past (see her Out of the Shtetl: Making Jews Modern in the Polish Borderlands, published in 2004). Sinkoff has also rediscovered and critically appraised a long-forgotten novel The Wall (1950) by John Hersey, a narrative hybridizing fact and fiction, which draws on authentic historical documentation and disregards, at least in the authorial intention, the demands of literary imagination or the liberties of licentia poetica to present the background to the Warsaw Ghetto Uprising. Hersey's adherence to historical detail was possible thanks to a three-year study of archives, much of which utilized the translations done by Dawidowicz (the novel, let us note in passing, still awaits its rendition into Polish).

From Left to Right: Lucy S. Dawidowicz, the New York Intellectuals, and the Politics of Jewish History comprises four thematic, chronologically 
structured sections. Part 1 narrates Dawidowicz's childhood (she was born in the Bronx, NYC, as Lucy Schildkret), teenage years and the early time she, a daughter of Polish Jewish immigrants, spent in America attending Hunter College (1932-1936) and later Columbia University (though getting no degree from the latter); Part 2 focuses on the moments of her gaining intellectual maturity in Poland before WWII, working at the YIVO Institute of Jewish Research, Vilnius (1938-1939), and in New York City (1940-1946), where she was employed at the new office of the YIVO (Yidisher Visnshaftlekher Institut, established in 1925 in Vilnius, was relocated across the Atlantic during the war, becoming the Institute for Jewish Research, and now is a partner of the Center for Jewish History); Part 3 demonstrates the gradual process of Dawidowicz's metamorphosis from a Jewish woman, who was deeply immersed in the tradition of her parents into a truly American intellectual, who nevertheless decided to be the self-appointed envoy of East European Jewry to communicate their stance to the Jewish American community; Part 4 , which in its content best justifies the choice of the title for the whole biography, examines the link between Dawidowicz's modern Jewish mindset, which was heavily marked by her diasporic-cum-nationalistic views, and the midcentury reformulations of liberalism that went hand in hand with the rise of American neoconservatism in the late 1960s. She turned "from left to right" and stuck firmly in that deliberately chosen political position until the end of her life, never seeing the need to reconsider it critically with the benefit of hindsight. Sinkoff's study also brings numerous photographs from Dawidowicz's personal archive and, more importantly, reproductions of thirty-one letters to illustrate an impressive range of correspondents (e.g. Albert Einstein, Simon Wiesenthal, Alfred Kazin, and Noam Chomsky), and issues that she would come to grips with throughout her life.

Arguably, in such a brief, synoptic review as the present one, three aspects of Dawidowicz's career deserve particular attention, marking as they do decisive and watershed moments that testify to her active role in the preservation of Jewish heritage, her importance as a provocative, trailblazing historian, who disagreed with Raul Hilberg and Hannah Arendt in a discussion on Jewish resistance during the Holocaust, and her natural proclivity to act as a gadfly by ostensibly defining herself as an anti-feminist. In 1933, at the time when the Nuremberg racial laws were being implemented by the Nazis, young 
Dawidowicz suddenly lost interest in her favorite English poetry (she was passionate about Wordsworth and Keats) to immerse herself in Yiddish language and the history of the Yiddish-speaking Jews of Eastern Europe. That was the main reason for going, in 1938, to Vilnius to study both history and historiography at the Jewish Scientific Institute YIVO. The sojourn left an imprint on her academic preoccupations for the rest of her life, but it was far too short lasting due to the threat of imminent war. In the late 1940s she returned to Europe to volunteer in the American Joint Distribution Committee, the organization whose main purpose at the time was to stave off the mass starvation of Holocaust survivors living in the so-called Displaced Persons camps in Germany. Concurrently, she dedicated her efforts to collecting, reclaiming or virtually salvaging Yiddish and Hebrew manuscripts, documents, and all sorts of book publications that had been appropriated by the Nazis and frequently used as fire-starters. Now all the treasures were dispatched to find shelter in the YIVO archive vaults. Soon, in 1948, she married Szymon Dawidowicz, a survivor who lost his family and relatives during the liquidation of the Warsaw ghetto in 1943, and who after the war was employed as a research bibliographer at YIVO. As Sinkoff argues, it was more or less at that time that Dawidowicz showed the first signs of being attracted to the political right, and became notorious for her disputatious pronouncements. For example, in 1951 and 1952 she published two articles - one in the liberal The New Leader and another in Commentary, a magazine that was thought of as a platform for the debates that transformed some part of the Jewish left into the neoconservative right - in which she voiced her support for the court decision to convict and execute Julius and Ethel Rosenberg for their spying on behalf of the Soviet Union (specifically, for their passing on top-secret information concerning nuclear weapon designs). But a truly resonating, game changing publication was The War Against the Jews. 1933-1945, which earned her the reputation of a contrarian in the territory of Holocaust historiography, forcefully arguing that the "Final Solution" was not a mere surge of criminal acts, but an ideological aberration to eradicate the Jews, categorized by the Nazis as defiling strangers (the claim that does not, of course, spark much controversy anymore). Dawidowicz traces the seeds of the genocide in such distant sources as the early $20^{\text {th }}$ century agenda of the liberal-oriented Social Democrats, who, in her argumentation, often subscribed to the stereotypical view, inherited from the writings of the young Marx, that the 
Jew was a hawker worshiping mammon. The Nazis, so further reasoning goes, followed a repulsively sick logic, according to which in the war that they triggered nothing was of greater importance than the very act of killing Jews. After all, the freight trains transporting people to Auschwitz and other death camps were in full operation at a time when the German army desperately needed them for the Eastern front. Thus, Dawidowicz took issue with the most popular theories of Nazism at the time, notably with the Marxist view of racist and genocidal ideology as a means to protect German capitalism. Granted, a fraction of the bourgeoisie did give financial support to Hitler's party and gained considerable advantage from the gesture afterwards, but in general Nazism was a self-propelled social machinery, immune to rational influences, which aside class interests to satisfy its bureaucratically schemed blood-lust.

The publication was harshly criticized by Raul Hilberg, a notable historian himself (the author of the landmark three-volume The Destruction of the European Jews, published in 1961) and a former friend of Dawidowicz, for drawing "largely on secondary sources" and thus offering "nothing whatever that could be called new" (a doubtful accusation as she had collected a wide spectrum of documents in half a dozen languages). More specifically, however, the point of contention revolved around the alleged passivity of European Jewry when faced with the realities of mass deportations, ghettos and, finally, death camps. Here Dawidowicz drew on documentary material to unhesitatingly demonstrate that effective resistance was, in fact, an impossibility. She underlined the engagement of more politically aware Jews in underground activities (which were carried out on a larger scale than had been assumed for years), but their poor marksmanship, exhaustion resulting from prolonged starvation, and the might of the oppressors thwarted all their efforts to stop or at least slow down the machine of the "Final Solution." Sinkoff considers the contention between Dawidowicz and Hilberg against the social and intellectual fervor of the 1960s, with its rejection of the so-called "establishment." In this light, the heads of Ghetto Jewish Councils, e.g. Chaim Rumkowski (in Lodz) or Adam Czerniakow (in Warsaw) were frowned upon as the exemplars of the "establishment," who as collaborationists played into the hands of the Nazi oppressors. But, going against the grain of the rebellious epoch in which she lived, Dawidowicz presented them as people who had found themselves in a cul-de-sac, doing whatever was realizable to save at least a part of the ghetto community. 
The point made in The War that it is morally doubtful for those who did not experience persecutions to condemn the behavior of those who did was later reiterated in The Holocaust and the Historians (1983), a study of Holocaust historiography and a harsh critique of Bruno Bettelheim and Hannah Arendt. As Sinkoff remarks, in the 1980s, Dawidowicz's reputation and fame as a researcher of the $20^{\text {th }}$ century Jewish past declined seriously. The New Left historians - a label covering the group of scholars focusing primarily on social justice, i. e. the machinations of the powerful and the resistance of the powerless, and whose works followed trajectories in conjunction with the feminist, civil rights, and Black nationalist movements - depreciated "the significance of both anti-Semitism and the particularism of Jewish suffering during the Holocaust."

Finally, what perhaps deserves even greater prominence than it is given in Sinkoff's study is the fact that Lucy S. Dawidowicz, a woman who distinguished herself for constructing Holocaust awareness in postwar America, was an ardent anti-feminist. As Sinkoff points out Dawidowicz's mindset, "full of contradictions," operated essentially between two mutually exclusive categories: "Jew" and "non-Jew," sex (or gender) playing a marginal role in her intellectual reflection if compared with her manifest adherence to Jewishness. On her rightward route Dawidowicz simultaneously began a gradual interest in and, soon, observance of normative Jewish practice, albeit offhandedly dismissing the feminization of ritual. That attitude was extrapolated onto women's rights in general. Accordingly, feminism, together with other social movements that mushroomed in the late 1960s, was viewed as basically foreign to the original notion of American liberalism, which had grown out of individual and not collective rights. Put differently, for Dawidowicz feminism was nothing more than the noisy pleading of a group that saw itself as deserving special privileges ("a politics of resentment"). As for her own milieu, she discounted the prevalent opinion that Jewish women were notoriously confined in a stifling and cramped prison of patriarchal rules and valuations. In what from today's perspective seems naïve, she believed that a genuine intellectual could be assessed on the basis of merit and achievement, regardless of sex.

The so-far easily observable scholarly indifference to Dawidowicz's critical and historical achievement can perhaps be put down to a number of factors: her unyielding devotedness to Jewish particularism, her growing right-wing 
views that in the end became her most recognizable marker, or, last but not least, her strong opinions on the postwar sex/gender revolution in culture. If this is really so (as I believe it is), the great asset of Sinkoff's study lies in its restrained maneuvering between the Scylla of unreflective apologia and the Charybdis of hasty condemnation. In this respect, her well-written, informative study of what may be called the 'irresistible charm of radicalism' is, in my opinion, the yardstick of unbiased biographical investigation for all academics embarking on an analogical task, and nothing less than an intellectual feast for general readers. Last but not least, the very title that Sinkoff has chosen, From Left to Right, aptly describes Dawidowicz's intellectual journey, but perhaps inadvertently, and more generally, also names a certain sprit (Zeitgeist) that tellingly hovers over America these days. Still, I am not certain whether this was Sinkoff's hidden intention when starting to write and putting the final touches to the book.

\section{References}

Sinkoff, N. (2020). From Left to Right: Lucy S. Dawidowicz, the New York Intellectuals, and the Politics of Jewish History. Wayne State University Press. 